\title{
The Many Meanings of Judicial Independence: Examples from British North America
}

\author{
Jim Phillips
}

\begin{abstract}
This article argues that there will not be an 'end of turns', but that the turn to contextual legal history in the 1960s remains the most potent, enduring turn the discipline has undergone. The varying meaning of judicial independence in nineteenth-century British North America illustrates this. It represented and was influenced by grand constitutional principle, the struggle for colonial autonomy, local control over public finances, and judicial fear of popular involvement in the removal process. Contextualism and complexity is examined here through the lens of judicial independence in three British North American colonies - the colonists worked within the essential paradigm of the inherited British Constitution.
\end{abstract}

\section{INTRODUCTION}

Legal history, among its many other virtues, surprises, intrigues, and frustrates us in equal measure. When we closely examine a recognisable legal phenomenon in historical context we find that words used in the past invariably had different meanings than they do now, that they often had multiple meanings, and that the transition from past to present has rarely been a simple and linear one. Those who look to history to justify the present by finding origins, and/or to celebrate and venerate a practice or a concept, are invariably disappointed.

These observations are as true of the idea of judicial independence, the subject of this essay, as of any other subject. Writing in 1997 in the Provincial Judges Reference, the Supreme Court of Canada's most comprehensive modern analysis of judicial independence, then Chief Justice of Canada Antonio Lamer stated that it was 'at root an unwritten constitutional principle', one 'whose origins can be traced to the Act of Settlement of 1701'. He was referring to judicial appointments on good behaviour rather than at pleasure, which he also said was a principle not created but 'recognized and affirmed' by the provisions for good behaviour appointments in the British North America Act which created the Dominion of Canada and laid out its Constitution. ${ }^{1}$ In fact, while the Act of Settlement was a significant moment in English constitutional history, ${ }^{2}$ it played

$1 \quad$ Reference re Remuneration of Judges of the Provincial Court of Prince Edward Island, et al [1997] 3 SCR 3 [83] (Lamer J).

2 For a useful succinct account of the establishment of the principle and its operation in the 18th century see David Lemmings, 'The Independence of the Judiciary 
a much reduced role in North America before and after the American Revolution, for it was not part of the English Constitution transplanted across the Atlantic. Good behaviour appointments came to the United States as part of the post-revolution settlement, ${ }^{3}$ and were not instituted in the various colonies which comprised the second empire, including the colonies which in the late 18th and 19th centuries were collectively known as British North America.

Moreover, while good behaviour appointment was debated and demanded in some parts of British North America in the 19th century, it was never the only aspect of judicial independence that concerned both advocates and critics. For some judicial independence was as much about what we would now term the separation of powers, the removal of judges from seats on colonial governing councils. For others it was about the appointment of judges rather than their tenure, and often it concerned judicial salaries - what they should be and who should pay them. Good behaviour appointment was at some times and in some places opposed by the very judges it was supposed to protect, and it invoked debates about how judges should be removed once they were protected from arbitrary Crown dismissal. Judicial independence was also both connected to wider issues of imperial policy and to political and economic disputes within colonial fragments.

Before getting to the substance of this article, a further word about legal history, its past and its future. This essay began as a lecture, part of a series held at Griffith University which was built around the notion of 'turns' in legal historical scholarship, variously biographical, comparative, narrative, cultural and performative. I was asked to consider 'the end of turns' and 'the future of the past'. My argument, perhaps a cheeky one, was that legal history made its most important 'turn' some 40 years ago, in the 1970s, when the study of the law's past became truly historicist. While taking both the law and legal institutions seriously, historians nonetheless placed them in the mainstream of historical research and interpretation. Henceforth, legal history was never again an examination of abstract forms represented through disembodied texts. ${ }^{4}$ I traced this most important turn to the extremely well known work of Douglas Hay and Morton Horwitz, which were and remain exemplars of a profound change, which I termed the contextualist turn and the turn that introduced the sometimes baffling complexity with which I began this article. By contextualism I mean simply that even those aspects of legal development and institutions seen as most unrelated to other aspects of history - in one case private law

in the Eighteenth Century' in P Birks (ed), The Life of the Law: Proceedings of the Tenth British Legal History Conference (London, 1993) 125.

3 For the American colonies, see Joseph H Smith, 'An Independent Judiciary: The Colonial Background' (1976) 124 University of Pennsylvania Law Review 1104; John McLaren, Dewigged, Bothered and Bewildered: British Colonial Judges on Trial, 1800-1900 (Osgoode Society for Canadian Legal History and University of Toronto Press, 2011) ch 2.

$4 \quad$ For a fuller treatment of what follows, see Jim Phillips, 'Why Legal History Matters' (2010) 41 Victoria University of Wellington Law Review 293. 
doctrine and in the other the apparently absurd rituals and ridiculously punitive practices of English criminal justice - could be explained, indeed needed to be explained, by reference to the broader society in which they operated. By complexity I mean simply what the word usually means. Within each analysis we saw contested and multiple causation, contradiction aplenty, the survival of the old with the emergence of the new, the struggle of ordinary people as well as elites to make sense of their world and to shape it according to their needs and wants - all of the things which makes history at one and the same time the most difficult and most illuminating of all disciplines.

Hay's remarkable 1975 article 'Property, Authority and the Criminal Law' explained the English criminal justice system of the 18th century as a product of the prevailing political, economic and social structures. ${ }^{5}$ What had seemed to many contemporaries, and to previous historians, as both fundamentally irrational and fundamentally disassociated from other historical developments became both rational and intimately related to broader concerns. Hay showed historians, especially the new social historians of that period, that law mattered, that it could not be ignored as mere superstructure, that it was a subject that deserved and required the serious attention of historians, and that it was, as EP Thompson famously said, 'imbricated', overlapping with everything else. ${ }^{6}$ Horwitz's The Transformation of American Law 1780 to $1860^{7}$ was a doctrinal history, dealing with tort, contract and property. In explaining developments in those areas, he argued that the judges instrumentally shaped doctrine to facilitate commercial and industrial development. Horwitz showed lawyers that they could not continue to treat the development of legal doctrine as an autonomous exercise in uncritical description. Legal rules, and the judges who shaped them, were actors in the real and messy world of political and economic change.

Both works spawned an enormous literature of refutation. ${ }^{8}$ They were said to paint too simplistic a picture of law as merely derivative of politics

$5 \quad$ D Hay, 'Property, Authority and the Criminal Law' in D Hay, P Linebaugh and EP Thompson, Albion's Fatal Tree: Crime and Society in Eighteenth Century England (1975, 2nd ed, 2011).

6 EP Thompson, The Poverty of Theory and Other Essays (Monthly Review Press, 1978).

$7 \quad$ Morton J Horwitz, The Transformation of American Law 1780 to 1860 (Harvard University Press, 1977). Horwitz had his predecessors, most notably Willard Hurst, who drew attention to the relation between law and economy, but it was Horwitz who put this relationship into the spotlight: see especially JW Hurst, Law and Economic Growth: A Legal History of the Lumber Industry in Wisconsin, 1836-1915 (Harvard University Press, 1964).

8 The literature is too voluminous to cite extensively. Among the best contributions arguing against the Horwitz thesis is P Karsten, Between Law and Custom: High and Low Legal Cultures in the Lands of the British Diaspora - The United States, Canada, Australia and New Zealand 1600-1900 (Cambridge University Press, 2002). See also for a survey of the debate many of the articles in AL Brophy and DW Hamilton (eds), Transformations in American Legal History: Essays in Honour of Professor Morton J Horwitz (Harvard University Press, 2009). For 
and economics, and thus historians delved into the ways in which law could indeed be seen as relatively autonomous, influential on as well as influenced by other developments. From this came a rich literature on the intellectual history of the law. Both were also said to be wrong when their theses were applied to other times and places. Hence we got voluminous comparative case studies emphasising the importance of particular periods and locations. Both were said to be too concerned only with class and economic relations, and in response legal historians took on writing the legal history of gender and racialisation, among other phenomena. In short, they took on many of the 'turns' highlighted in the lecture series, which have collectively provided a much richer sense of the complexity of legal norms and institutions by examining how law affected ordinary people and how those people both resisted foreign cultural intrusions and made sense of their own world. But these later turns have not been fundamental turnarounds, but rather the turning of corners into by-ways, by-ways that have provided a constant set of often surprising insights. They have done that while still being rooted, consciously or unconsciously, in the ideas of contextualism and complication that emerged from the 1970s.

In what follows I examine contextualism and complexity through the lens of judicial independence in three British North American colonies, from c 1825 to Canadian Confederation in 1867. I will use each of the colonies to illustrate a different aspect of the complex meaning of judicial independence. Upper Canada (now the province of Ontario) received good behaviour appointments in 1834, the second colony in the empire to do so, Nova Scotia in 1848, and New Brunswick not until 1867, when it joined in the Confederation compact of that year. ${ }^{9}$ Upper Canada was founded in 1791, when it was carved out of the western section of the old colony of Quebec, which had been acquired by Britain from France in the 1763 Peace of Paris. It was populated largely, though not exclusively, by American loyalist emigrants. Nova Scotia was the first of what became the British North American colonies to be acquired by Britain, from France, in the Treaty of Utrecht of 1713. Britain did little or nothing with the colony until 1749 when it established the city of Halifax as a counter weight to the French garrison of Louisbourg. That city, and the colony as a whole, was populated from 1760 s by European immigration and, more importantly, by the northern movement of people from New England. It was part of the expansion of the pre-revolutionary American

those commenting directly or indirectly on Hay see especially P King, Crime, Justice and Discretion in England, 1740-1820 (Oxford University Press, 2000), and JM Beattie et al, 'Symposium on Property, Authority and the Criminal Law' (2006) 10 Legal History 13.

9 This essay does not discuss the other two eastern British North American colonies, Lower Canada and Prince Edward Island. Lower Canada's experience was similar to that of Upper Canada, except that the granting of good behaviour appointments was delayed until 1843 by the Lower Canadian rebellion of 1837 1838, while Prince Edward Island, like New Brunswick, never received good behaviour appointments in the colonial period. 
Colonies and distinct from those colonies principally in the fact that it chose not to join the revolution. New Brunswick, was, like Upper Canada, the product of post-revolutionary migration. After 1783 tens of thousands of American loyalists migrated north to the northern regions of what was Nova Scotia, and in 1784 the newly populated areas were hived off into a new colony.

\section{UpPer CANada: Judicial Independence as Colonial REFORM PROJECT}

The Upper Canadian story of judicial independence is largely one of arguments over constitutional principle, and can best be told in three stages. First, while local reformers had raised the issue of judicial independence as early as 1826 , what made it a major cause was the dismissal of Judge John Willis in 1828. ${ }^{10} \mathrm{~A}$ successful and well-regarded equity barrister and legal author, Willis had been appointed to the court from England the previous year, and very quickly came to believe, rightly, that the colonial judiciary was an intimate part of the local governing elite, popularly styled the Family Compact. This oligarchy believed in the recreation in North America of a society based on monarchical and aristocratic values, a reaction to the democratic and republican society to the south. The Family Compact exercised a monopoly of political power through its control of the executive and legislative councils, power which the assembly, to whom the executive was not responsible, was largely unable to resist. The compact used the law and the courts to silence their political enemies. ${ }^{11}$ The judiciary was clearly part of the Compact. All Chief Justices prior to the 1830s were members of both the executive and legislative councils, and some of the puisne judges were on one or the other council as well while sitting on the bench.

10 For the Willis affair see McLaren, above n 3, 74-87. See also A Wilson, 'John Walpole Willis' DCB online; LA Johnson, 'John Walpole Willis' Career in Upper Canada, 1827-1828' (1993) 85 Ontario History 141; and, on the Chancery Court question, John Weaver, 'While Equity Slumbered: Creditor Advantage, a Capitalist Land Market, and Upper Canada's Missing Court' (1990) 28 Osgoode Hall Law Journal 871.

11 The literature on the Family Compact and the law is large. See principally P Romney, Mr Attorney: The Attorney-General for Ontario in Court, Cabinet and Legislature, 1791-1899 (Osgoode Society for Canadian Legal History and University of Toronto Press, 1986), and the same author's 'From Constitutionalism to Legalism: Trial by Jury, Responsible Government, and the Rule of Law in Canadian Political Culture' (1989) 7 Law and History Review 121; C Wilton, "Lawless Law": Conservative Political Violence in Upper Canada, 1818-1841' (1995) 13 Law and History Review 111. The historiography is well reviewed in an essay which actually takes some issue with the critique, arguing that in their everyday work in criminal cases the judges acted impartially and properly: see P Oliver, 'Power, Politics, and the Law: The Place of the Judiciary in the Historiography of Upper Canada' in GB Baker and J Phillips (eds), Essays in the History of Canadian Law: Volume VIII - In Honour of RCB Risk (Osgoode Society for Canadian Legal History and University of Toronto Press, 1999) 444-447. 
By the 1820s a reform movement against this Family Compact was a force to be reckoned with in the Assembly, and the new judge Willis came to identify with their concerns. He criticised his fellow judges on a variety of issues and, in June 1828, delivered his coup de grace, holding that the Court of King's Bench was improperly constituted. The 1794 statute creating the court provided that, 'His Majesty's Chief Justice ..., together with two puisne judges, shall preside' in the court. ${ }^{12}$ Willis held that this meant that all three judges had to be present at all times, and as Chief Justice William Campbell was out of Upper Canada, he adjourned the court. In so holding, Willis was not simply causing a short term delay in proceedings. He was calling into question the entire work of the court since its inception, for there had been many occasions on which it had sat without a full complement. Lieutenant-Governor Maitland acted swiftly and suspended Willis, thereby making it abundantly clear what were the consequences of at pleasure appointment.

The dismissal takes us to the second phase of the story, which saw a vociferous and sustained set of protests against Willis' suspension by reformers, who exploited the affair to win their first majority in the Assembly. The demand for good behaviour appointments was couched in terms of British constitutionalism, as evidenced by a March 1829 Assembly address to the Crown. The address noted that the people of England were fortunate to enjoy good behaviour appointments, and rhetorically asked why 'a portion of Your Majesty's free and glorious empire' was not also 'equally interested and entitled to have justice administered amongst us by independent judges'. ${ }^{13}$ Reformers thus insisted that they were entitled, as British subjects, to enjoy all of the benefits of British constitutional practice. In the meantime, Willis was replaced by James Macaulay, a high Tory, executive councillor, and close confidant of Lieutenant-Governor Maitland. Macaulay was in no danger of dismissal by the Crown, precisely because he was so firmly ensconced in the family compact.

London initially refused to countenance any change in the tenure of judges. It had a long-standing policy of insisting that colonial judges be loyal to colonial executives and always as a consequence made their tenure 'at pleasure'. Colonial Office officials explained the reasoning for this policy in some detail before a major parliamentary committee of 1828 . The chief government witness before the Canada Committee, as it was called, was James Stephen Jnr, long-time counsel to the Colonial Office. His objection to good behaviour appointments in the colonies centred on the composition of colonial benches. ${ }^{14}$ On the one hand, judges needed to be appointed from the English bar because of a lack of competent lawyers in the colonies. At the same time, it was impossible to get the best men to

12 An Act to establish a Superior Court of Civil and Criminal Jurisdiction, Statutes of Upper Canada 1794, c 2.

13 Upper Canada Assembly, Address to the Crown, March 1849, in Upper Canada Assembly Journals, 14 March 1829.

14 What follows is from Report from the Select Committee on the Civil Government of Canada, British Parliamentary Papers, Cd No 569, 1828, Minutes of Evidence, 21 June 1828, 228-230. 
take colonial appointments: 'The gentlemen of the bar who go out to the colonies as judges are of course seldom selected from the most successful members of the legal profession', he argued, 'They are frequently young men, and ... they are seldom well known'. The problem with the appointment of the second rate, Stephen went on, was that, ' $[t]$ hey go to a small society, where as a matter of course, (for it may be said to be the natural state of all small societies) they find violent feuds and parties. How they will conduct themselves in such situations must always be a matter of conjecture, and doubtful experiment'. Judges could easily become 'a little intoxicated' with elevation to the bench, and, '[i]f the judge were independent and irremoveable,' he would 'too often become the ally of one or other of the local parties'.

There was an irony in all this. Stephen's insistence that judges had to come from England was made at a time when the bench was rapidly becoming an indigenous one, and in fact Willis was the last Upper Canadian judge to be appointed directly from England. As the Macaulay example shows, there were plenty of home-grown Tories to be placed on the bench. And this fact led the Upper Canadian reformers to add to their demands for independent judges, a concurrent demand that all judges 'for many years to come' be 'selected from the English bar'. Only such outsiders would be 'as free as possible from the entanglements of family connexions, the influence of local jealousies, and the contamination of provincial politics'. ${ }^{15}$

London changed its tune in 1830, not primarily because of developments in the colony, but because of a change of government at home. Lord Grey's Whig administration, which came to power in November 1830, was more prepared than its Tory predecessors to listen to the demands of colonial reformers. In 1830-1831, London issued a series of directives against judges sitting on governing councils, ${ }^{16}$ and also acceded to demands for good behaviour appointments. But the latter came with a condition. The Assembly had to provide a permanent, guaranteed fund for the payment of judicial salaries, which had previously been provided from Crown revenues. London insisted that judicial independence was not simply a question of tenure, it was also one of financial independence from the other branches of government. As Colonial Secretary Goderich put it in 1831, judges should be 'independent ... of the Royal Authority and of the pleasure of the popular Branch of the Legislature', and to achieve the latter it was an 'essential condition' that 'an adequate and permanent provision should be made for the judges'. ${ }^{17}$

15 Address to the Crown, in Upper Canada Assembly Journals, 14 March 1829.

16 See WR Riddell, 'Judges in the Executive Council of Upper Canada' (1921) 20 Michigan Law Review 716, 730-731; and Viscount Goderich to Sir Peregrine Maitland, 7 December 1830, and Viscount Goderich to President William Black, 7 December 1830, both in Copies or Extracts of Correspondence from Nova Scotia etc, British Parliamentary Papers, Cd No 579, 1839.

17 Earl Goderich to Lieutenant-Governor Colborne, 8 February 1831, in Report of the Public Archives for 1935, 257. See also Earl Goderich to Lieutenant-Governor Colborne, 24 December 1830, in Report of the Public Archives for 1935, 251-253. 
This third phase, getting the Assembly to agree on a guaranteed fund, occupied three more years, until 1834, when a short two paragraph Act provided for good behaviour appointments and removal by the Crown only on a joint address of both houses of the local legislature. ${ }^{18}$ The delay was not caused by disagreement over whether judges' salaries should be guaranteed, but over a variety of side issues, including the question of how judges, if they were to enjoy good behaviour appointments, could be removed if necessary. The obvious method, which was ultimately adopted, was to replicate the English practice of the joint address. But this gave the Assembly a role in judicial removal, and conservatives resisted this. Proposals were floated by the more conservative members of the Assembly for some kind of separate "tribunal" for the "impeachment" of judges. ${ }^{19}$ They went nowhere, but they do show a distrust of democracy which was to be replicated more than a decade later in the debate on good behaviour appointments in Nova Scotia.

The principle of good behaviour appointments had been won, but arguments over judicial independence did not go away. Reformers continued their attacks on the colony's judiciary and its ties to government in the years leading up to the Rebellion of 1837. But they increasingly shifted their focus to financial questions. They saw, and vociferously complained about, that a simple additional method of ensuring judicial fealty was the system of discretionary pensions and salary supplements. As a famous 1837 Assembly report on grievances stated, 'as long as these pecuniary inducements can be held out to those occupying the judiciary we cannot consider it practically in a better or safer condition than it used to be'. ${ }^{20}$

\section{Nova Scotia: Judges And Democracy}

I turn to my second example, the colony of Nova Scotia. Here the story is very different and, I think, rather unusual. If the Upper Canadian story can be called largely one of debate over a constitutional principle, the Nova Scotia story is better labelled as 'the perils of democracy'. Although there were controversies over the judiciary in the 1830s and $1840 \mathrm{~s}$, a matter to which I will return, there was no discussion at all of good behaviour appointments until the colony moved to responsible government in 1848 . It was simply assumed by both the liberal administration in power and by the Colonial Office that a change in judicial tenure would be a natural concomitant of that broader political transformation, and indeed one of the first acts of the Assembly in the 1848 session was to pass a Bill to that effect, an act to which London assented without demur. As elsewhere

18 An Act to Render the Judges of the Court of King's Bench in this Province Independent of the Crown, Statutes of Upper Canada 1834, c 2.

19 When a good behaviour Bill was introduced at the end of 1832 by William Bent Berzcy, a conservative, it contained a provision 'for the appointment of a tribunal, wherein [the judges] may be impeached,' as well as one 'for granting them a retired allowance': Upper Canada Assembly Journals, 12 December 1832. Upper Canada Assembly Journals, 1835, Appendix A-21, 12. 
judicial tenure was converted to good behaviour and a judge could be removed following a joint address of the Legislative Council and the Assembly to the Crown.

Supporters of the Bill in the Assembly made the standard arguments. They stressed the importance of judicial independence in principle, and noted that the provisions for removing judges tracked long-standing English constitutional arrangements. Attorney-General James Boyle Uniacke waxed lyrical that henceforth a judge "need not quail under the frown, nor tremble at the displeasure of those who sit in the highest places of the land - he will be independent alike, of the Sovereign and the subject'. ${ }^{21}$

There was, however, fierce opposition from a group that one might have expected to welcome the change - the judges of the Supreme Court and the Master of the Rolls, whose tenure was similarly altered. They fought unsuccessfully for two principal amendments - one to require a two-thirds majority in both the Assembly and Legislative Council, the other to add a rider that no address for removal could be effectual 'unless some petition containing a specific charge or accusation against such judge verified by affidavit' was presented. ${ }^{22}$ It is not difficult to discern the concern underlying these proposed amendments - a fundamental distrust of the popular will. Conservative leader and future Nova Scotia Supreme Court Judge James W Johnston argued that the Bill, 'so far from making it [the bench] independent strikes a fatal blow at its liberty; instead of being a principle conferring Independence, it will have the effect of placing the minds of judges in a complete state of vassalage'. The Bill, he went on, 'will have the effect of removing every bulwark which guards personal liberty, the protection of property and the dearest rights and privileges of Englishmen'. Why? Because the Assembly was given a role in the removal process. The Assembly had many lawyer members, 'the very men who are most likely to be brought into the collision with the Bench'. It was also now, with the advent of responsible government, a forum in which party politics mattered. In the new order of things judges would be fearful for their position, they would 'tremble' when 'they take their seats to try those cases which arouse the feelings of party', for fear that they would 'call down the vengeance of those in power, they would, again, 'tremble lest some influential person may be offended and revenge some fancied wrong'. ${ }^{23}$

The conservatives knew that the major difficulty with their position was that the Bill replicated English arrangements; indeed this fact put them in the contradictory position of appealing to the British tradition of judicial independence while simultaneously refuting the arrangement which supposedly guaranteed that. In proposing the amendment for a two-thirds majority, MHA and lawyer James DeWolfe Fraser took this problem head on. What was good for Britain was not necessarily good for

$21 \quad$ Novascotian, 20 March 1848.

22 Nova Scotia Assembly Journals, 3, 7, 14, and 15 March 1848.

23 Novascotian, 20 March 1848. 
the colony. The distinction lay in the different composition of the upper house. The House of Lords consisted of men of rank and accomplishment, unconnected with the Commons. In Nova Scotia the Assembly was like the Commons, but the Legislative Council was also more like the Commons than the Lords. It consisted of 'persons ... selected from among ourselves - from the people - on account of their political standing'. Thus 'in this country, vacancies must be filled by persons friendly to the party in power'. Given that, said Fraser, there would be no safety for the judge - he would be merely responsible to popular opinion. ${ }^{24}$

The judges did not give up the fight when their arguments failed in the Legislature, and appealed to London. ${ }^{25}$ Chief Justice Brenton Halliburton carefully delineated the calculations necessary to support his argument in favour of a two-thirds majority clause. The Legislative Council had 21 members, so that 11 constituted a majority; the Assembly had 51 members, so that 26 was a majority. Thus the votes of only 37 people were needed to remove a judge. Lest such a notion be thought 'chimerical,' Halliburton went on to note that a quarter of the Assembly members were lawyers, a group 'who must continually be brought into collision with the judges'. A good number of other Assemblymen were traders, 'a class of men whose business frequently brings them into court, and who, when unsuccessful, are not unnaturally displeased with the judge who decides against them'. Lawyers and litigants were 'often too apt to indulge feelings of personal dislike, and to attribute to prejudice what has proceeded from principle'. Halliburton also saw dangers in the patronage system which would inevitably be a product of responsible government. Administrations wished to reward their friends, and the Bill provided a mechanism for getting rid of sitting judges in order to put supporters in their place..$^{26}$

Lieutenant-Governor Sir John Harvey thought the judges' objections 'much exaggerated', and indeed, using Halliburton's own word,

24 Ibid.

25 Brenton Halliburton, 'Observations on a Bill, An Act to render the Judges of the Supreme Court, and the Master of the Rolls, independent of the Crown, and to provide for their removal', 22 March 1848; and Alexander Stewart to Lieutenant-Governor Harvey, 24 March 1848; both in Nova Scotia Legislative Council Journals, 1848, Appendix 29.

26 Halliburton was partly right about the problem of patronage. Although no judge was ever removed, nor was any impeachment attempted, in order to replace him with a party supporter, or for any other reason, the verdict of history has been very critical of the other connection between responsible government and the Act of 1848 - the appointment process became local, and soon a victim of party patronage. Historians have castigated the 'appalling quality of many appointments' in the decades after 1848, and in addition the scandal of Premier William Young appointing himself Chief Justice in 1860 certainly sullied the court's reputation. The fallout from that affair had hardly died down when the conservatives took their revenge, appointing their long-time leader James W Johnston to the court in 1864. See generally P Girard, "The Supreme Court of Nova Scotia, Responsible Government, and the Quest for Legitimacy, 1850-1920' (1994) 17 Dalhousie Law Journal 430, 432. 
'chimerical', as did the Colonial Office, and they were roundly rejected. ${ }^{27}$ We can, however, find an explanation for these arguments. Since the early 1830s a number of issues had made the Supreme Court judges controversial figures in the colony. ${ }^{28}$ Judicial remuneration was the principal one. In the early 1830 s the local government and the judges tried to persuade the Assembly to pay the judges more, and this produced an incensed reaction against what was seen as an elitist demand for more by those already better positioned than the vast majority of the inhabitants. When the judges linked better salaries to independence, they were told, in the stinging words of one Assemblymen, that 'independence may be attained, not so much by multiplying the means of indulgence, as by restraining the desires'. That is, 'the wants of nature are easily supplied, but the cravings of rank and luxury are insatiable and know of no bounds'. ${ }^{29}$

But the bitterest and most long-standing financial dispute involving the judges was over their collection of fees from litigants as a form of salary supplement. It was the subject of often heated invective and became one of the central planks of the reform campaign of the $1830 \mathrm{~s}$. It was not just about money; very quickly the anti-fee campaign alleged that the taking of fees was illegal. The fees were consistently excoriated - they were described as 'exactions' and as 'unconstitutional and repugnant to all just notions of liberty', and a number of fee abolition Bills passed the Assembly. Those Bills were all blocked in the Council, where sat Chief Justice Halliburton. For reformers no better example could be found, reform leader Joseph Howe argued, of the imperfect structure of the upper branch' of government than the fact that Halliburton used his seat in council to block abolition of 'the illegal and unnecessary Fees taken by the Judges of the Supreme Court'. Howe certainly did not mince his words: 'when Bills abolishing the illegal exaction of One Thousand Pounds per annum taken by the Judges in the shape of fees, are year after year burked in the other end of the Building, by a Body over which presides a gentleman largely interested in that exaction, is it unfair to attribute to him some agency in their destruction, or to wish that he had not been placed in a situation where his public duty interferes so much with his private interests?' ${ }^{30}$

The fees question was in one sense resolved in 1838 when Colonial Secretary Glenelg fashioned a compromise; the fees would no longer be collected and as compensation the judges would each receive a salary

27 Lieutenant-Governor Harvey to Earl Grey, 10 April 1848, in Nova Scotia Assembly Journals, 1849, Appendix 7.

28 This section is taken from J Phillips and B Miller, 'Too Many Courts and Too Much Law: The Politics of Judicial Reform in Nova Scotia, 1830-1841' (2012) 30 Law and History Review 89; and J Phillips and B Miller, 'Exactions made upon the most distressed part of His Majesty's Subjects: The Public Debate over Judicial Fees in Nova Scotia in the 1830s' in P Bastien et al (eds), Justice et espaces publics en Occident, du moyen age à nos jours (Presses de l'Université du Québec, 2014).

29 Novascotian, 24 March 1830.

$30 \quad$ Novascotian, 16 February 1837. 
supplement from the Crown revenues. But the compromise created its own problems. As in other colonies, including Upper Canada, London was keen to have the Assembly provide a permanent civil list in return for surrender of the Crown. Civil List Bills were introduced in the Assembly on many occasions between 1838 and 1846, but none became law. A consistent sticking point, right to the end, was judicial salaries. The Assembly generally wanted to reduce salaries, on the grounds that the colony could not afford them, but London always refused, arguing that incumbents were entitled to all the emoluments of their offices. More importantly, the Assembly also did not wish to provide for that part of the existing salaries which represented the compensation for fees no longer being collected. The reason was simple - the fees had been illegal, and it would not provide a salary supplement as compensation for their being given up. The matter was not finally resolved until 1849, when the Assembly eventually capitulated, perhaps because by then only two of the judges remained from 1838 and were entitled to the supplement.

The point of this diversion into financial questions is to suggest that when considering their attitude towards the judicial independence bill of 1848 the judges had plenty of evidence of their rough treatment by the Assembly - and they deeply resented the attacks on them. In 1836 one of them, William Blowers Bliss, complained about being 'slandered and abused in every shape by a set of low designing, artful scoundrels' who published 'misstatements and false reasoning'. ${ }^{31}$ A decade later he was equally dismayed that Assemblymen were still at it, 'abusing the Court', with some members 'declaring that we are party men who have neither the confidence of the Country nor of the bar'. ${ }^{32}$ Little wonder, perhaps, that the Nova Scotia judges preferred a theoretically unstable tenure at the whim of the Crown to what they saw as a practically highly unstable tenure because of the new involvement in judicial removal of the elected branch of the Constitution.

\section{New BRUnswick}

My final example is the colony of New Brunswick, and the principal theme here, a sub-theme elsewhere, is money. Colonial judges in New Brunswick never received good behaviour appointments. That came about only when the colony joined the Canadian confederation in 1867, the British North America Act of that year providing for a common form of judicial tenure in all provinces. Indeed on only one occasion was the matter even raised in the colonial legislature, and that, as I will explain below, was a rather cheeky attempt to placate the judges by Assemblymen trying to deprive them of a substantial portion of their income.

$31 \quad$ William Bliss to Henry Bliss, 14 November 1836, Nova Scotia Archives and Records Management, Bliss Papers, MG 1, vol 1599, No 33.

32 William Bliss to Henry Bliss, 2 April 1847, Nova Scotia Archives and Records Management, Bliss Papers, MG 1, vol 1599, No 107. 
From 1837, when the Assembly agreed on a civil list deal with the Colonial Office, the salaries of the New Brunswick Supreme Court judges were set at c.£980 sterling for the Chief Justice and c $£ 675$ sterling for the puisne judges. ${ }^{33}$ Each also received a fluctuating amount of about $£ 150$ in local currency (£135 sterling) from fees. ${ }^{34}$ From the early 1840 s the more radical politicians in the Assembly argued that these salaries were too high, but nothing came of that. What brought about a serious assault on judicial salaries was the deep depression that followed the ending of imperial preferences in 1848. Probably no colony felt this more acutely than New Brunswick, which had built its considerable prosperity on supplying Britain with lumber, and, to a lesser but still substantial extent, on shipbuilding and trade. No longer sustained by the Navigation Acts, and unable to access American markets protected by high tariffs, New Brunswickers took out their economic woes on office holders, specifically on their salaries. ${ }^{35}$

In 1849 the Assembly reduced the salary of any future Chief Justice, future puisne judge, and future Master of the Rolls, by one-third. ${ }^{36}$ Some in the Assembly also tried to make the reductions apply to incumbents, but this failed. ${ }^{37}$ The following year further legislation passed by the Assembly did make the reductions applicable to incumbents. The rationale was simple. As stated in an Assembly resolution which dealt extensively with the economic situation, 'the salaries of public officers ought at all times to be subject to such modifications by the Legislature as the exigencies of the Province ... may render necessary, irrespective of the tenure by which such officers hold their appointments'. ${ }^{38}$ In short, times had changed, and no-one should be immune from the consequences of that change.

The reformers also clearly had a sense that judges should not be so much above the people as to amount to a kind of colonial aristocracy. Assemblyman Charles Fisher, in objecting to an alternative scheme to reduce expenses by reducing the number of judges, insisted that the colony needed the judicial staffing levels it had, but that salaries should be 'consistent with the circumstances of the country, and proportioned to

33 See Civil List Act, Statutes of New Brunswick 1837, c 1, made perpetual by Civil List Act, Statutes of New Brunswick 1838, c 52. The Act does not specify amounts, for these see the Appendices to New Brunswick Assembly Journals 1838 and 1839, which give salaries in local currency.

34 For fees see the Appendix to the Report of the Commissioners of Judicial Inquiry, in New Brunswick Assembly Journals, 1842.

35 For the politics of the period see WS MacNutt, New Brunswick A History: 1784-1867 (Macmillan, 1963) chs 12, 13; DGG Kerr, 'Head and Responsible Government in New Brunswick' (1938) 17 Report of the Annual Meeting of the Canadian Historical Association 62; WS MacNutt, 'The Coming of Responsible Government to New Brunswick' (1952) 33 Canadian Historical Review 111.

36 An Act for the reduction of Judicial Salaries in this Province, Statutes of New Brunswick 1850, c 1. The Act was passed in 1849 but appears in the 1850 statutes because its implementation was delayed pending London's approval.

37 See New Brunswick Assembly Journals, 3 March 1849.

38 New Brunswick Assembly Journals, 24 April 1850. For the legislation, see New Brunswick Assembly Journals, 22, 24 and 25 April 1850. 
the income of the more respectable inhabitants employed in professional, mercantile, agricultural and mechanical pursuits'. ${ }^{39}$ Many speakers in the Assembly decried excessive judicial salaries which absorbed money that should be spent elsewhere. Lawyer William End insisted that 'a great portion of the distress and embarrassment of the province is fairly attributable' to overly high judicial and other official salaries, which had for too long been 'soaking up the revenues ... which ought to have been expended in relieving our crippled trade' and establishing 'roads, bridges schools and works of public utility'. Instead 'a kind of spurious aristocracy' had been created'. ${ }^{40}$

The Colonial Office in London would not agree. It accepted that the new system of responsible government introduced in 1848 could include the setting of judicial salaries in the future. But it would not accept reductions for incumbent judges, and the immediate salary reduction bills passed in 1850, 1851 and 1852 were all refused assent. The reasons were two-fold. Less importantly, London maintained that the Civil List compact of the 1830s was not amendable, because it represented the honour of the Crown in settling with officials who held office under it. More importantly, London was adamant that reductions 'violate the great principle of the independence of the Judicial Bench'. That is,

[T] he independence of those officers of all sinister influence, is one of the chief safeguards of any free constitution. Their independence of the crown has been long ago secured by the established policy of this country, both at home and in all her Colonies. But their independence of popular influence is not less essential, and can only be secured ... by maintaining the principle that their Salaries shall be fixed by permanent appropriation, not provided for by annual votes. ${ }^{41}$

The judges themselves made the same point, noting that if salaries could be altered so easily, it will most seriously affect the independence of the judicial office ... by making the income of a judge the subject of annual or constant discussion in the Legislature'. The constitutional principle of judicial independence was, they said, 'a paramount object in all parts of the world within the pale of the British Constitution'. They knew they only had at pleasure appointments, but considered that fact unimportant compared to guaranteed salaries. They asked 'of what avail is a tenure of office, substantially during good behaviour, as we have been assured that of the Judges is, if the income from it can at any time be wholly or partially taken away?' In a slightly different context the judges also echoed the kinds of concerns raised by their Nova Scotia counterparts about the make-up of the Assembly: 'It frequently happens that the Members of Assembly are themselves suitors in the Courts of Justice, or the relations of suitors; and will the dependence of the judges on their

39 Statement of Charles Fisher, in New Brunswick Assembly Journals, 12 April 1851.

$40 \quad$ Fredericton Head Quarters, 13 May 1850.

41 Earl Grey to Sir Edmund Head, 25 November 1850, in New Brunswick Assembly Journals, 15 February 1851. 
votes ... be likely to promote the independence of those who are entrusted with the administration of justice. ${ }^{42}$

Three additional points should be noted here. First, at the same time that they passed the salary reduction bill in 1850 the Assembly also passed one for the abolition of judicial fees without compensation, which would have of course reduced judicial remuneration even further. This too was repassed in subsequent years and consistently rejected by London. ${ }^{43}$ Second, one of the judges who protested both these measures had already felt the effects of salary reduction. James Carter had been on the bench since 1836, but when promoted to Chief Justice in 1851 he was only entitled to the lower salary legislated in 1849 as he was not an incumbent Chief Justice. As he ruefully pointed out, his salary had gone down by $£ 50$ in local currency as a result. The abolition of fees would reduce it by a further $£ 150$. He was paid less than incumbent puisne judges. ${ }^{44}$

Third, there was only one legislative initiative in this period to introduce good behaviour appointments. It came in 1852, when for the third time in three years a Bill for fee abolition without compensation was introduced in the Assembly. Its sponsor, Amos Botsford, coupled it with another Bill, to alter judges' tenure to good behaviour, which went nowhere after first reading. Unfortunately there are no sources to explain its introduction or its summary dismissal. But one wonders if it was not a cheeky reminder to the judges of what real independence was about. ${ }^{45}$

Demands for judicial salary reductions and fee abolition without compensation tailed off as it became clear that London was never going to consent to either. The movement also lost impetus as economic conditions improved with American reciprocity and a railway building boom. But the few brief years in which judicial salaries dominated public debate in New Brunswick highlights the multi-variant nature of the meaning of judicial independence. For those without a comfortable seat on the bench, judges had too much independence from the vicissitudes of the trade cycle. Conversely, the judges themselves seemed to care little for the great constitutional principle that had emerged from the final defeat of the Stuarts. They were content to be vassals of the Crown, and feared above all the perils of democratic cost-cutting.

\section{$\mathrm{V}$ Conclusion}

These three British North American examples of the debate over judicial independence in the second quarter of the 19th century demonstrate that the general concept took on very particular meanings in a variety of

42 New Brunswick Supreme Court Judges and Master of the Rolls to Sir Edmund Head, 2 August 1850, in New Brunswick Assembly Journals, 3 March 1851.

43 See the documents collected in New Brunswick Assembly Journals, 3 March 1851.

44 Chief Justice James Carter to Earl Grey, 8 May 1851, in JW Lawrence, The Judges of New Brunswick and their Times (Acadiensis Press, 1983) 356.

45 New Brunswick Assembly Journals, 29 and 30 January 1852. 
contexts. In Upper Canada it meant principally a key part of the British Constitution - freedom from arbitrary Crown dismissal - did not apply to the colony and this absence tainted colonial political structures and practices. It also, to the colonial power, meant guaranteed salaries. In Nova Scotia, it concerned not dismissal by the Crown so much as removal for misbehaviour, with the judges and their conservative supporters fearful of any role for the elected element of government in that removal process. The same concern about popular interference with judges animated the New Brunswick debate, albeit not over a removal procedure but over the stability of salary levels for incumbents. Judicial remuneration indeed, had a long shelf life as a mainstay of British policy in the colonies; the demand for a civil list delayed the advent of good behaviour appointments in Upper Canada in the 1830s and the inviolability of the civil list stymied reformers' retrenchment plans for New Brunswick in the 1850s.

Perhaps a fitting final point to make is one about what judicial independence, for all its complexity, did not mean in British North America. Judges came under plenty of attacks from reformers in the northern colonies, over a variety of issues, and in some respects the history of complaints about them in the Canadian colonies mirrors debates in the United States. But nobody in British North America ever suggested that a solution lay in an elected judiciary. As Jed Shugerman has recently persuasively argued, the triumph of the elective principle for State judges in the mid-19th century was ultimately brought about by a belief that election was a better guarantee of independence than any other method of judicial selection and removal. ${ }^{46}$ Whatever dissatisfactions there were in the imperial fragments, all colonists worked within the essential paradigm of the inherited British Constitution.

$46 \quad$ J Shugerman, The Peoples' Courts: Pursuing Judicial Independence in America (Harvard University Press, 2012). 